ISSN 1392-3196 / e-ISSN 2335-8947

Zemdirbyste-Agriculture, vol. 101, No. 1 (2014), p. 35-40

DOI $10.13080 /$ z-a.2014.101.005

\title{
Seed size effect on yield quantity and quality of maize (Zea mays L.) cultivated in South East Baltic region
}

\author{
Hanna SULEWSKA, Karolina ŚMIATACZ, Grażyna SZYMAŃSKA, \\ Katarzyna PANASIEWICZ, Hanna BANDURSKA, Romana GŁOWICKA-WOŁOSZYN \\ Poznan University of Life Sciences \\ Dojazd 11, 60-632 Poznan, Poland \\ E-mail: sulewska@up.poznan.pl
}

\begin{abstract}
Fractionation of seeds is a process commonly used by breeding and seed production companies. Separation of seeds into small, medium and large size fractions depends on a thousand kernel weight and thus on the content of the endosperm of the seeds, which is used in the process of embryo germination. Research showed that large seeds were characterized by a higher field germination capacity and generally seedlings had greater weight compared to those obtained from small seeds. The question then arises whether such fractionation would promote plant yield improvement. Yields of maize (Zea mays L.) plants of cv. 'Boruta' obtained from different size fractions (of different thousand kernel weight) were evaluated in the years 2005-2007. A three-year field experiment showed that yielding of the plants depended on the seed size fraction and decreased with an increase in the size of maize seeds sown. Moreover, in the experiment the germination value of seeds was assessed in cold $\left(10^{\circ} \mathrm{C}\right)$ and warm $\left(25^{\circ} \mathrm{C}\right)$ tests. The highest germination capacity in both the warm and the cold test $(79.0 \%$ and $74.0 \%$, respectively) was observed in the small seed size fraction. Germination of large seeds in the cold test was by $6.71 \%$ lower (a significant difference) than that of small seeds. The amylolytic activity of three fractions was also examined as indicated by dry and swollen seeds. The results showed the highest activity of amylases in small seeds $(7.33 \mathrm{mg}$ maltoze $\mathrm{g}$ dry matter-1 $\left.\mathrm{min}^{-1}\right)$ and the lowest in large seeds $\left(4.12 \mathrm{mg}\right.$ maltoze $\mathrm{g}$ dry matter-1 $\left.\mathrm{min}^{-1}\right)$.
\end{abstract}

Key words: amylase, seed size, seed value, seed vigour.

\section{Introduction}

Maize continues to be an important crop with multiple applications, both for feed and food as well as industrial purposes and its grain production is currently highly profitable.

The average maize yield per hectare in Poland is $7.18 \mathrm{t} \mathrm{ha}^{-1}$. While it is not as low as in Pakistan $\left(1.74 \mathrm{t} \mathrm{ha}^{-1}\right)$ it is not equal to that in other most important maize growing countries of the world (New Zeland $-9.78 \mathrm{t} \mathrm{ha}^{-1}$, Chile $9.40 \mathrm{t} \mathrm{ha}^{-1}$, Italy $-9.33 \mathrm{t} \mathrm{ha}^{-1}$, Austria $-9.18 \mathrm{t} \mathrm{ha}^{-1}$, USA $-8.44 \mathrm{t} \mathrm{ha}^{-1}$ ). There are many factors responsible for this level of yielding; some of these are low quality seed, poor seed germination and poor seedling vigour depending on the agro-ecological zones. Among these factors, germination and seedling vigour are greatly influenced by seed size; therefore attention should be given to the selection of good quality seed. In recent years, there has been an increasing interest in maize growing for grain in Poland. In 2012, the area cropped to grain maize increased by 539.3 thousand ha compared to 2011 , which represents a $61.8 \%$ increase (Central Statistical Office (CSO), 2012).

One of the conditions for obtaining good yields of maize, among others, is adequate plant density per unit area and uniform distribution of seeds in a row. This effect can be achieved by sowing certified seed material using precision sowing machines. Breeding and seed companies usually fractionate the seeds according to the size and shape into fractions of small, medium, large and round and flat. By purchasing certified seed, regardless of fraction, one can be sure that it is characterised by high seed quality value.

Sizing of seeds, called fractionation, is based on the idea that some of the physical characteristics of seeds affect their vigour. Therefore, this procedure is often treated as enhancing seed quality value. These issues, in other species of plants, have already been researched by many authors who showed that larger triticale seeds have a higher germination rate, resulting in better field emergence. There is also a concept that the yield obtained from plants grown from large seeds is higher than that from smaller ones. However, other studies conducted on maize undermined this hypothesis completely (Sulewska, Koziara, 2006). Therefore, the question arises whether seed fractionation really affects crop yield, and hence whether while purchasing the seeds one should pay attention to seed fraction. One of the factors affecting seed vigour is the activity of amylases catalyzing hydrolytic degradation of starch into simple 
sugars, which are substrates necessary for metabolic processes, conditioning the growth and development of the embryo (Lauriére et al., 1992).

The aim of the study was to determine the effect of seed fraction on seed quality and on the growth and grain yield of maize.

\section{Materials and methods}

The study was conducted in 2005-2007 in Swadzim, near Poznań, in the fields of the Experimental and Educational Center in Gorzyń belonging to the University of Life Sciences in Poznań. The subject of the investigation was maize (Zea mays L.) cv. 'Boruta' (FAO 230), with the following thousand kernel weight (TKW) fractions: small $-268 \mathrm{~g}(\mathrm{~S})$, medium $-340 \mathrm{~g}(\mathrm{M})$ and large $-410 \mathrm{~g}(\mathrm{~L})$. The seeds from the same batch were commercially fractionated at the Smolice Plant Breeding Ltd. and packed in original bags. The field experiment was conducted on the luvisol soils, sand texture, shallowly deposited on light clay belonging to a good rye complex (FAO, 2006). Maize was sown after winter wheat; soil management was performed in accordance with proper agricultural technology for this species and directions for use. Weather conditions varied between the years of the study (Fig.). In 2005, there were semi-drought periods in April, June and September, while in 2006 drought periods occurred in June, July and September. The growing seasons of 2005 and 2006 should therefore be considered as not meeting the requirements of plants in terms of water supply. The beginning of the growing season of 2007 was characterised as being less favourable for the growth and development of maize plants. There was a drought in April, but it should be noted that May-July precipitation coincided with the period of the greatest water needs for maize.

Basic seed value parameters were evaluated under laboratory conditions according to the ISTA 2010 (International Seed Testing Association) methodology. Furthermore, the cold germination test in a climate chamber "Mytron" (Mytron Bio- und Solartechnik GmbH, Germany) was performed for all maize seed fractions. Fifty seeds were sown in four replications in tissue rolls with soil collected from the field in which maize had been grown. Germination was carried out initially for 7 days at $10^{\circ} \mathrm{C}$ and then for 6 days at a temperature of $25^{\circ} \mathrm{C}$. Seed vigour assessment was based on two tests: seedling growth and seedling growth rate. These tests were performed on samples of 25 seeds placed in a roll of paper tissue in four replicates. Wet samples were placed in a water thermostat at an optimal temperature of $20^{\circ} \mathrm{C}$.

In addition, EC 3.2.1.1 amylase activity was determined in each of the three fractions of dry seeds and after swelling, as well as the degree of swelling. Samples of dry seeds of known weight were placed in water at a temperature of $20^{\circ} \mathrm{C}$ for 24 hours. After that, the seed surface was dried with paper tissue, the seeds were weighed and the degree of swelling was calculated. In order to determine the activity of amylases, $5 \mathrm{~g}$ of dry milled seeds of each fraction were weighed, $100 \mathrm{~cm}^{3}$ of $0.5 \% \mathrm{NaCl}$ was added, incubated for $30 \mathrm{~min}$ at $20^{\circ} \mathrm{C}$ and then centrifuged for $30 \mathrm{~min}$ at $3000 \mathrm{~g}$. Samples of swollen seeds corresponding to a weight of $5 \mathrm{~g}$ of dry grains were crushed with a homogenizer "Ultra-Turrax" (IKA, Germany) followed by the next steps as for dry seeds.
Amylase activity in the supernatant was determined by the method proposed by Bernfeld methodology using the reducing ability of starch hydrolysis products, which in an alkaline solution reduce the nitrite group of dinitrosalicylic acid. Enzyme activity was expressed as mg maltose released per $1 \mathrm{~g}$ of dry seeds per minute. All analyses were performed in five replications.
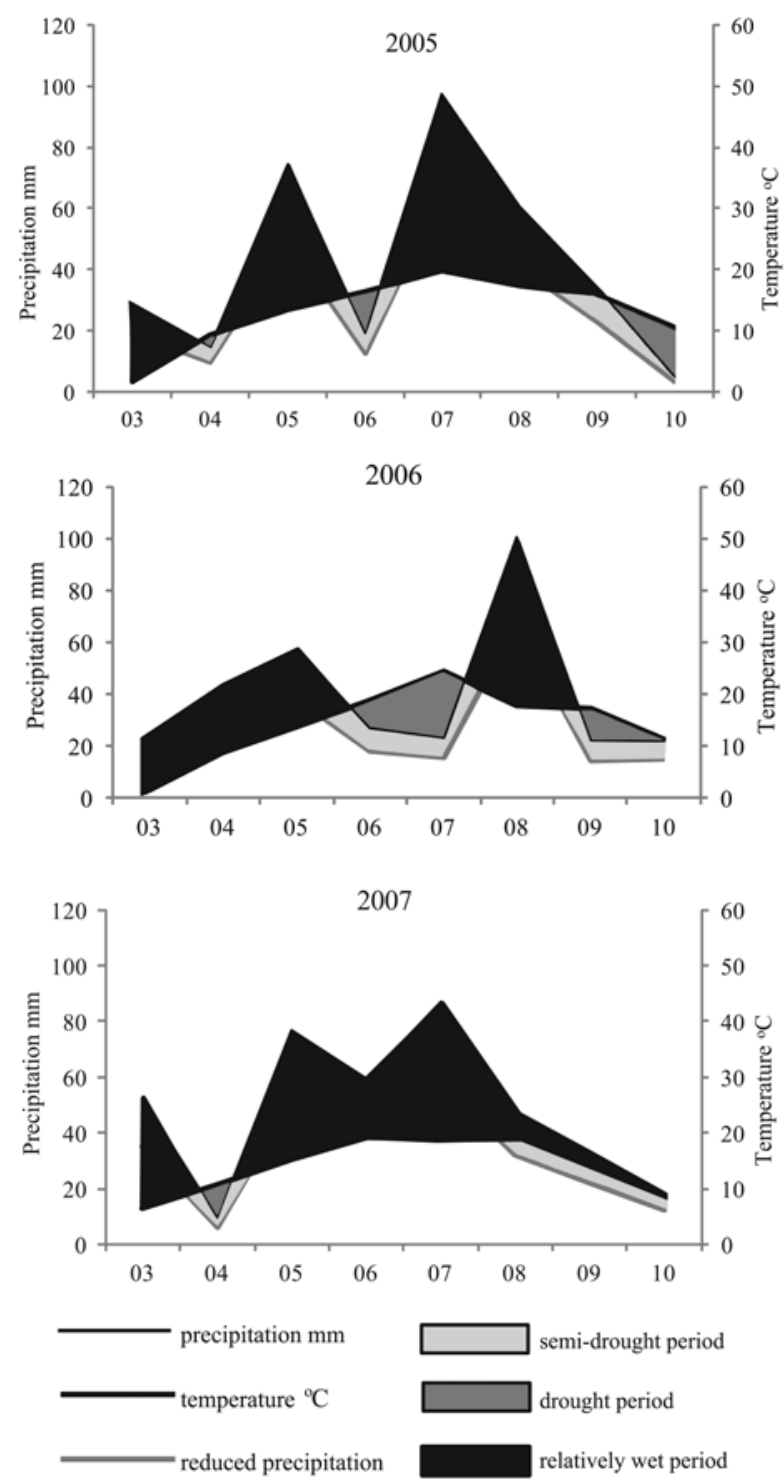

Figure. Climate graphs according to Walter characterizing weather conditions in Swadzim

The relationship between seed fractions and the produced yield was determined using the analysis of variance for single factor experiments. Analysis of variance $A N O V A$ was performed for the blocks to investigate the effect of seed fraction on the yield, TKW, ear number, ear volume and grain moisture. Analysis was performed separately for the results obtained in each year of the study and a total for the years 2005-2007. Assumption of homogeneity of variance was examined based on Levene's test. In the case of non-homogeneity with the ANOVA assumptions, the Kruskal-Wallis test was conducted. In the case of a statistically significant effect of the fraction, Tukey's multiple comparisons test was performed. 


\section{Results and discussion}

In 2006 and 2007, the yield of the small fraction was significantly higher than that of the large fraction. Similar results were obtained by Sulewska and Koziara (2006) in an experiment with maize cv. 'Clarica', in which grain yields from plants grown from seeds of the medium and large fractions declined, when compared with those of plants grown from the small seed fraction and amounted to $1.3 \mathrm{dt} \mathrm{ha}^{-1}$ and $2.3 \mathrm{dt} \mathrm{ha}^{-1}$, respectively. Similarly to the present study, Graven and Carter (1990) also showed a downward trend when sowing large maize seeds. Royo et al. (2006) indicated the opposite effect that the yield of durum wheat plants grown from large grains was higher by $16 \%$ compared with that from plants grown from small seeds. Their investigation also proved that large seeds produced greater plot stands, but the plants had fewer tillers, leaves and spikes and less green area and dry weight than the plots from small seeds. Also Rukavina et al. (2002) obtained a significantly higher yield from planting larger seeds rather than smaller seeds, regardless of spring barley cultivar. A study made by Enayat Gholizadeh et al. (2012) showed that by increasing maize seed size the commercial yield increased and the seeds with higher vigour produced stronger seedlings, thus increasing the establishment rate of the seedlings and creating a better green cover in the field, which finally produced more vigorous plants. Chaudhry and Ullah (2001) in their study of maize found no differences in the yield of plants grown from large and small seeds. In our study in 2005 and 2007 the yield was characterised by low variability, while in 2006 a large variation was found in grain yield for the small and large seed fractions, while it was average for the medium fraction (Table 1). This variation was connected with the varied weather conditions in the growing seasons. Both in 2005 and 2006 there were periods of drought that caused $15 \%$ yield reductions, especially in 2006 when the drought occurred in the months of greatest water needs of maize (Fig.). However, in 2005 there were no statistically significant differences between all the factions in terms of yield. Analysis of the results obtained from the years 2005-2007 showed no statistically significant differences; however, a trend was shown that grain yields in the experiment decreased with the increasing TKW in seeds used for sowing (Table 1).

Table 1. Yields $\left(\mathrm{dt} \mathrm{ha}^{-1}\right)$ obtained from three seed fractions

\begin{tabular}{|c|c|c|c|c|c|c|c|}
\hline \multirow{2}{*}{ Year } & \multirow{2}{*}{ Seed fraction } & \multicolumn{4}{|c|}{ Descriptive statistics } & \multirow{2}{*}{$P$-value } & \multirow{2}{*}{$\begin{array}{l}\text { Homogenic groups } \\
\text { (Tukey's test) }\end{array}$} \\
\hline & & $\min$ & $\max$ & mean $\pm \mathrm{SD}$ & CV (\%) & & \\
\hline \multirow{3}{*}{2005} & $\mathrm{~S}$ & 42.9 & 51.9 & $47.3 \pm 3.8$ & 8.0 & \multirow{3}{*}{$0.666 \mathrm{~ns}$} & \\
\hline & M & 43.2 & 49.1 & $46.7 \pm 2.5$ & 5.5 & & \\
\hline & $\mathrm{L}$ & 47.2 & 49.2 & $48.2 \pm 0.8$ & 1.6 & & \\
\hline \multirow{3}{*}{2006} & $\mathrm{~S}$ & 11.5 & 37.2 & $24.4 \pm 10.5$ & 43.0 & \multirow{3}{*}{$0.046^{*}$} & B \\
\hline & M & 8.7 & 15.7 & $12.2 \pm 2.8$ & 23.3 & & $\mathrm{AB}$ \\
\hline & $\mathrm{L}$ & 4.5 & 10.4 & $7.4 \pm 2.4$ & 32.4 & & A \\
\hline \multirow{3}{*}{2007} & $\mathrm{~S}$ & 105.8 & 115.1 & $110.5 \pm 4.6$ & 4.1 & \multirow{3}{*}{$0.005^{* *}$} & B \\
\hline & M & 96.7 & 107.1 & $102.9 \pm 4.5$ & 4.4 & & $\mathrm{AB}$ \\
\hline & $\mathrm{L}$ & 94.9 & 99.9 & $97.1 \pm 2.6$ & 2.7 & & A \\
\hline \multirow{3}{*}{$2005-2007$} & $\mathrm{~S}$ & 11.5 & 115.1 & $60.7 \pm 38.6$ & 63.5 & \multirow{3}{*}{$0.670 \mathrm{~ns}$} & \\
\hline & M & 8.7 & 107.1 & $53.9 \pm 39.2$ & 72.7 & & \\
\hline & $\mathrm{L}$ & 4.5 & 99.9 & $50.9 \pm 38.4$ & 75.3 & & \\
\hline
\end{tabular}

SD - standard deviation; CV - coefficient of variation; * - statistically significant differences $(p<0.05), * *$ - statistically highly significant differences $(p<0.01)$, ns - no statistically significant effect on tested trait $(p>0.05) ; \mathrm{S}-$ small $(268 \mathrm{~g}), \mathrm{M}-$ medium $(340 \mathrm{~g}), \mathrm{L}-$ large $(410 \mathrm{~g})$ seed fraction

Plants grown from the small seed fraction produced grain yields by $17.0 \mathrm{dt} \mathrm{ha}^{-1}(2006)$ and 13.4 $\mathrm{dt} \mathrm{ha}^{-1}$ (2007) higher than those grown from the largest fraction, and the differences were statistically significant. The number of ears decreased with an increase in the TKW, which was the trait that determined the grain yield (Table 2). By sowing seeds of the small, medium and large fractions 5.1, 5.0 and 4.8 ears $\mathrm{m}^{-2}$ were produced, respectively; however, the significance of the recorded density was not confirmed statistically. Only in 2006 the medium seed fraction produced a significantly higher number of ears when compared to the large fraction. For the other studied traits there were no statistically significant differences between the two seed fractions. The small and medium seed fractions were characterised by a tendency to a greater TKW than the large fraction, with the difference amounting to 5.0 and $3.7 \mathrm{~g}$, respectively. In a study by Liu et al. (2012) a thousand seed weight in large-seeded plants of oilseed rape was $13 \%$ greater than that in small-seeded crop. The lowest grain moisture at harvest was recorded in plants grown from the small seed fraction $(28.9 \%)$, while it was the highest in the case of the large fraction $(29.2 \%)$. In a study by Rukavina et al. (2002) grain moisture content at harvest significantly decreased when large and medium-size seeds were sown in comparison to the small and very small. Ear volume for the small seed fraction was $235.9 \mathrm{~cm}^{3}$, for the medium fraction it increased by $2.3 \mathrm{~cm}^{3}$, whereas for the large fraction it was the lowest and it amounted to $229.4 \mathrm{~cm}^{3}$.

According to Goggi et al. (2008), seed quality is a very important factor that determines the early development and growth of agricultural crops. Therefore, all studies to improve yield and nutrition of plants should take into account seed quality, which as this author defined is a vitality and vigour character, facilitating the production of normal seedlings within a very wide range of conditions found in the field. Seed size depends on the genotype and environmental conditions in which they developed, and that has an impact on seedling survival, growth and development. Seed size plays a major role 
Table 2. Biometric characters of maize seed fractions in the years of the study

\begin{tabular}{|c|c|c|c|c|c|c|c|c|c|}
\hline \multirow[t]{2}{*}{ Year } & \multirow{2}{*}{$\begin{array}{l}\text { Seed } \\
\text { fraction }\end{array}$} & \multicolumn{2}{|c|}{$\begin{array}{l}\text { Thousand kernel weight } \\
\mathrm{g}\end{array}$} & \multicolumn{2}{|c|}{$\begin{array}{c}\text { Number of ears } \\
\mathrm{m}^{-2}\end{array}$} & \multicolumn{2}{|c|}{$\begin{array}{c}\begin{array}{c}\text { Ear volume } \\
\mathrm{cm}^{3}\end{array} \\
\end{array}$} & \multicolumn{2}{|c|}{$\begin{array}{c}\text { Moisture } \\
\%\end{array}$} \\
\hline & & mean $\pm \mathrm{SD}$ & $P$-value & mean $\pm \mathrm{SD}$ & $P$-value & mean $\pm \mathrm{SD}$ & $P$-value & mean $\pm \mathrm{SD}$ & $P$-value \\
\hline \multirow{3}{*}{2005} & $\mathrm{~S}$ & $136.9 \pm 16.9$ & \multirow{3}{*}{$0.741 \mathrm{~ns}$} & $7.4 \pm 0.6$ & \multirow{3}{*}{$0.104 \mathrm{~ns}$} & $238.9 \pm 29.5$ & & $24.8 \pm 0.6$ & \multirow{3}{*}{$0.506 \mathrm{~ns}$} \\
\hline & M & $142.2 \pm 7.9$ & & $6.9 \pm 0.4$ & & $240.7 \pm 21.7$ & $0.944 \mathrm{~ns}$ & $24.6 \pm 0.8$ & \\
\hline & $\mathrm{L}$ & $136.3 \pm 2.9$ & & $7.5 \pm 0.1$ & & $234.9 \pm 11.2$ & & $25.2 \pm 0.9$ & \\
\hline \multirow{3}{*}{2006} & $\mathrm{~S}$ & $356.4 \pm 1.7$ & \multirow{3}{*}{$0.378 \mathrm{~ns}$} & $0.7 \pm 0.1 \mathrm{ab}$ & \multirow{3}{*}{$0.023^{*}$} & $197.8 \pm 27.4$ & & $36.5 \pm 1.1$ & \multirow{3}{*}{$0.527 \mathrm{~ns}$} \\
\hline & M & $344.2 \pm 26.5$ & & $1.0 \pm 0.5 \mathrm{~b}$ & & $201.1 \pm 19.9$ & $0.623 \mathrm{~ns}$ & $37.0 \pm 0.1$ & \\
\hline & $\mathrm{L}$ & $343.9 \pm 12.4$ & & $0.4 \pm 0.2 \mathrm{a}$ & & $189.1 \pm 18.0$ & & $37.0 \pm 0.5$ & \\
\hline \multirow{3}{*}{2007} & $\mathrm{~S}$ & $341.4 \pm 7.4$ & \multirow{3}{*}{$0.828 \mathrm{~ns}$} & $7.4 \pm 0.3$ & \multirow{3}{*}{$0.084 \mathrm{~ns}$} & $271.1 \pm 8.3$ & & $25.4 \pm 0.1$ & \multirow{3}{*}{$0.942 \mathrm{~ns}$} \\
\hline & M & $344.3 \pm 7.3$ & & $7.0 \pm 0.3$ & & $272.8 \pm 13.0$ & $0.610 \mathrm{~ns}$ & $25.4 \pm 0.3$ & \\
\hline & $\mathrm{L}$ & $339.5 \pm 11.5$ & & $6.6 \pm 0.9$ & & $264.1 \pm 11.9$ & & $25.4 \pm 0.3$ & \\
\hline \multirow{3}{*}{ 2005-2007 } & $\mathrm{S}$ & $278.2 \pm 105$ & \multirow{3}{*}{$0.723 \mathrm{~ns}$} & $5.1 \pm 3.3$ & \multirow{3}{*}{$0.589 \mathrm{~ns}$} & $235.9 \pm 38.0$ & & $28.9 \pm 5.7$ & \multirow{3}{*}{$0.702 \mathrm{~ns}$} \\
\hline & M & $276.9 \pm 100.6$ & & $5.0 \pm 3.0$ & & $238.2 \pm 35.0$ & $0.797 \mathrm{~ns}$ & $29.0 \pm 5.9$ & \\
\hline & $\mathrm{L}$ & $273.2 \pm 101.5$ & & $4.8 \pm 3.3$ & & $229.4 \pm 34.6$ & & $29.2 \pm 5.8$ & \\
\hline
\end{tabular}

SD - standard deviation; * - statistically significant differences $(p<0.05)$, ns - no statistically significant effect on tested trait $(p>0.05) ; \mathrm{S}-$ small $(268 \mathrm{~g}), \mathrm{M}-$ medium $(340 \mathrm{~g}), \mathrm{L}-$ large $(410 \mathrm{~g})$ seed fraction

in the process of germination and it is usually associated with seedling vigour, which is very important for future crop plants (Nerson, 2002). Evans and Bhatt (1977) found that in cereals also the rate of seedling growth and seedling vigour depend on seed size, protein content, germination resistance and the genotype. Seed size is a characteristic of seed quality influencing seedling growth and establishment. Studies on the relationship between seed size and early growth have been conducted since the early $21^{\text {st }}$ century. Most investigators reported a positive relationship between seedling vigour, improved stand establishment and higher productivity of cereal crops with plants originating from large seeds when compared to those grown from smaller seeds (Nik et al., 2011). Test values of seedling growth and seedling growth rate in our study were higher for the large seed fraction (Table 3 ). Similarly, Farahani et al. (2011) reported obtaining visually more vigorous seedlings from the large seed fraction of wheat. Also Ries and Everson (1973) in their study on wheat yield showed a relationship of yield and seedling vigour with seed size and its protein content. Ries and Everson (1973) obtained a correlation of 0.69 to 0.87 between seedling vigour and seed size. Also Evans and Bhatt (1977) in their study showed a significant positive correlation between seed size and seedling vigour. According to Chastin et al. (1995), higher seed vigour of larger seeds is connected with larger nutrient reserves in the seeds; hence the larger seeds produce seedlings with greater early growth and an increased competitive ability against weeds and pests. Moreover, according to Seshu et al. (1987), lower seed vigour in many cultivated species is connected with lower plant yielding. Our findings do not confirm this relationship. In the study by Nik et al. (2011), coleoptile length was strongly correlated with the size of wheat seeds. Large seeds produced longer coleoptiles than small seeds. It was also shown that the production of dry matter in plants grown from large seeds was significantly higher than in plants grown from small seeds. In addition, the plants grown from large seeds were characterised by a greater vigour than those grown from small seeds. Also in a study by Ries and Everson (1973) carried out on wheat, coleoptiles developing from large seeds were significantly longer than those from smaller seeds. Hendrix et al. (1991) showed, however, that larger seeds generally produce larger seedlings. The germination percentage, seedling dry weight, seedling vigour and seedling length increased with the increasing seed size in durum wheat (Chaffai, Louchichi, 2013). Contrary test results were obtained in the study by Panasiewicz et al. (2008), in which among the compared cereals maize was the only species which showed seedling growth and its rate to be greater for the small seed fraction. However, in the cited studies the small seed fraction had the highest germination rate, which was confirmed statistically.

Seed germination in wheat depends on seed size, which has a greater effect on the germination percentage than the germination and emergence index (Singh, 2003). Moreover, it influences components and the yield of grain. In our laboratory analyses, the relationship between the seed size fraction and seed germination capacity was also shown (Table 3 ). A clearly inferior germination capacity was observed in the large seed fraction; however, this difference was not confirmed statistically.

Seeds with a lower TKW showed a higher germination percentage than larger seeds. Astudy by Hojjat (2011) revealed that large-sized seeds of lentil genotypes have high seedling survival, growth and establishment rates under unfavourable conditions. Germination rate of naked oat also increases to $95.16 \%$ as seed size decreases 91.16\% (Mut, Akay, 2010). A study of Msuya and Stefano

Table 3. Seed value and vigour of three maize seed fractions

\begin{tabular}{|c|c|c|c|c|c|c|c|c|c|}
\hline \multirow{3}{*}{$\begin{array}{l}\text { Seed fraction } \\
\text { Small (268 g) }\end{array}$} & \multicolumn{3}{|c|}{ Seed value } & \multicolumn{6}{|c|}{ Seed vigour } \\
\hline & $\begin{array}{l}\text { Germination } \\
\text { energy }\end{array}$ & \multicolumn{2}{|c|}{$\begin{array}{c}\text { Germination capacity } \\
\% \\
\end{array}$} & \multicolumn{2}{|c|}{$\begin{array}{l}\text { Seedling growth test } \\
\mathrm{cm}\end{array}$} & \multicolumn{2}{|c|}{$\begin{array}{l}\text { Seedling growth rate test } \\
\text { mg }\end{array}$} & \multicolumn{2}{|c|}{$\begin{array}{c}\text { Cold test } \\
\%\end{array}$} \\
\hline & 94 & 79.0 & & 6.54 & $\mathrm{~A}$ & 18.3 & A & 74.0 & B \\
\hline Medium (340 g) & 91 & 78.0 & & 7.57 & $\mathrm{AB}$ & 23.1 & $\mathrm{AB}$ & 70.0 & $\mathrm{AB}$ \\
\hline Large $(410 \mathrm{~g})$ & 89 & 74.0 & & 7.83 & $\mathrm{~B}$ & 25.2 & $\mathrm{~B}$ & 62.0 & A \\
\hline
\end{tabular}

A, AB, B - homogeneous groups (Tukey's test) 
(2010) on the evaluation of kernels from cobs of different sizes showed that the smallest grains germinate much faster than medium and large grains (from larger ears). However, dry matter content of seedlings grown from the smallest seeds was significantly lower than that in the case of the larger kernels. Probably the mechanism controlling seed vigour, responsible for how quickly it germinates is different from the one responsible for the vigour of the emerging seedlings. Thus, although small seeds germinate faster, large ones produce root systems and shoots more quickly after germination and are able to take up nutrients faster and assimilate them more quickly. The study also shows that the dry matter content of all organs in the plant seedlings was strongly correlated with seed size. In three varieties of sugar beet out of the five studied the greatest percentage of normal seedlings was observed in the case of the small and medium-sized seeds (Javad, Mohammad, 2011). A study by Kaydan and Yagmur (2008) showed a higher germination rate and seedling growth with an increase in triticale seed size. Also Khera et al. (2004) in their study conducted on seeds of Lebbek tree (Albizia lebbek (L.) Benth.), showed that the medium and large seeds had better germination characteristics in the laboratory and nursery than the largest and smallest seeds. In other species, i.e. A. nilotica and A. catechu, a positive dependence on seed size was observed for these characters. Nerson (2002) showed that small muskmelon seeds were characterised by the lowest germination and emergence rates as well as the slowest seedling growth. There are also studies indicating that seed size has no effect on germination. Navratil and Burris (1980) published an equation taking into account the number of tests that allow prediction of field emergence, with the cold test indicated as the best. Germination assessed using the cold test in our study decreased with an increasing weight of sown seeds, and significant differences were shown between the small and large seed fractions. Similar results for this test were obtained by Sulewska and Koziara (2006).

Germination of seeds is directly dependent on the activity of amylases contained therein. Studies with rice have shown that a greater germination capacity and higher germination vigour of seeds were connected with a higher activity of $\beta$-amylase (Nandi et al., 1995). The results recorded in this study indicate an increased amylase activity (Table 4) in the small seed fraction, which may be one of the factors contributing to their better germination. However, there was no effect of seed size on seed swelling rate.

Table 4. Amylase activity and the rate of soaking depending on seed fraction

\begin{tabular}{cccc}
\hline Trait & \multicolumn{3}{c}{ Seed fraction } \\
\cline { 2 - 4 } & small $(268 \mathrm{~g})$ & medium $(340 \mathrm{~g})$ & large $(410 \mathrm{~g})$ \\
\hline Activity of amylase & & dry seed & $4.12 \mathrm{~A}$ \\
mg maltoze g dry matter-1 $\mathrm{min}^{-1}$ & $7.33 \mathrm{~B}$ & $6.14 \mathrm{AB}$ & $3.10 \mathrm{~A}$ \\
\hline Activity of amylase & & swelled seeds & $7.71 \mathrm{~B}$ \\
mg maltoze g dry matter-1 $\mathrm{min}^{-1}$ & $6.12 \mathrm{AB}$ & 43.44 (without groups) & 43.20 (without groups) \\
\hline Soaking rate $\%$ & 43.60 (without groups)
\end{tabular}

$\mathrm{A}, \mathrm{AB}, \mathrm{B}$ - homogeneous groups (Tukey's test)

\section{Conclusions}

1. Plant yielding depended on the seed fraction used and it decreased with an increase in the size of seeds. Seed yield of the small and medium seed size fractions was higher by $17.0 \mathrm{dt} \mathrm{ha}^{-1}$ (2006) and $13.4 \mathrm{dt} \mathrm{ha}^{-1}$ (2007), respectively, when compared to the yield produced from the large seed fraction.

2. The share of germinating maize seeds in the cold test decreased with an increasing thousand kernel weight of seeds used for sowing.

3. Small grains were characterized by a higher amylase activity $\left(7.33 \mathrm{mg}\right.$ maltoze $\mathrm{g}$ dry matter $\left.{ }^{-1} \mathrm{~min}^{-1}\right)$ when compared to the large ones $(4.12 \mathrm{mg}$ maltoze $\mathrm{g}$ dry matter-1 $\mathrm{min}^{-1}$ ).

Received 17012013

Accepted 02072013

\section{References}

Chaffai A., Louchichi B. 2013. Effect of seed size on germination and establishment of vigorous seedlings in durum wheat (Triticum durum Desf.). Advances in Environmental Biology, 7 (1): 77-81

Chastin T. G., Ward K. J., Wysocki D. J. 1995. Stand establishment responses of soft white winter wheat to seedbed residue and seed. Crop Science, 35: 213-218 http://dx.doi.org/10.2135/ cropsci1995.0011183X003500010040x

Chaudhry A. U., Ullah I. M. 2001. Influence of seed size on yield, yield components and quality of three maize genotypes. Journal of Biological Sciences, 1 (3): 150-151 http://dx.doi.org/10.3923/jbs.2001.150.151
CSO 2012. Statistical yearbook of agriculture. Poland, Warsaw $<$ http://www.stat.gov.pl/gus/5840_4127_ENG_HTML. $\mathrm{htm}>$ [accessed 16012014 ]

Enayat Gholizadeh M. R., Bakhshandeh A. M., Shoar Dehgan M., Ghaineh M. H., Alami Saeid K. H., Sharafizadeh M. 2012. Effect of source and seed size on yield component of corn S.C704 in Khuzestan. African Journal of Biotechnology, 11 (12): 2938-2944

Evans L. E., Bhatt G. M. 1977. Influence of seed size, protein content and cultivar on early seedling vigor in wheat. Canadian Journal of Plant Sciences, 57: 929-935 http://dx.doi.org/10.4141/cjps77-133

FAO 2006. Guidelines for soil description ( $4^{\text {th }}$ ed.). Food and Agriculture Organization of the Unites Nations, p. 1-97

Farahani H. A., Moaveni P., Maroufi K. 2011. Effect of seed size on seedling production in wheat (Triticum aestivum L.), Advances in Environmental Biology, 5 (7): 1711-1715

Goggi A. S., Caragea P., Pollak L., McAndrews G., DeVries M., Montgomery K. 2008. Seed quality assurance in maize breeding programs: tests to explain variations in maize inbreds and populations. Agronomy Journal, 100 (2): 337 $343 \mathrm{http}: / /$ dx.doi.org/10.2134/agrojn12007.0151

Graven L. M., Carter P. R. 1990. Seed size and tillage system effect on corn growth and grain yield. Journal of Production Agriculture, 3 (4): 445-452 http://dx.doi.org/10.2134/jpa1990.0445

Hendrix S. D., Nielsen E., Nielsen T., Schutt M. 1991. Are seedling from small seeds always interior to seedlings from large seeds? Effects of seed biomass on seedling growth in Pastinaca sativa L. New Phytologist, 119: 299-305 http://dx.doi.org/10.1111/j.1469-8137.1991.tb01034.x 
Hojjat S. S. 2011. Effects of seed size germination and seedling growth of some lentil genotypes (Lens culinaris Medik.). International Journal of Agriculture and Crop Sciences, 3 (1): $1-5$

Javad A., Mohammad R. A. 2011. The effects of seed size on germination and early seedling growth of pelleted seeds of sugar beet. Journal of Applied Sciences Research, 7 (8): $1257-1260$

Kaydan D., Yagmur M. 2008. Germination, seedling growth and relative water content of shoot in different seed sizes of triticale under osmotic stress of water and $\mathrm{NaCl}$. African Journal of Biotechnology, 7 (16): 2862-2868

Khera N., Sabena A. K., Singh R. P. 2004. Seed size variability and its influence on germination and seedling growth of five multipurpose tree species. Seed Science and Technology, 32 (2): $319-330$

Lauriére Ch., Doyen Ch., Thévenot C., Daussant J. 1992. $\beta$-amylase in cereals. Plant Physiology, 100: 887-893

Liu Y., Tang Z., Darmency H., Stewart C. N. Jr., Di K., Wei W., Ma K. 2012. The effects of seed size on hybrids formed between oilseed rape (Brassica napus) and wild brown mustard (B. juncea). PLoS ONE, 7 (6): e39705 http://dx.doi.org/10.1371/journal.pone.0039705

Msuya D. G., Stefano J. 2010. Responses of maize (Zea mays) seed germination capacity and vigour to seed selection based on size of cob and selective threshing. World Journal of Agricultural Science, 6 (6): 683-688

Mut Z., Akay H. 2010. Effect of seed size and drought stress on germination and seedling growth of naked oat (Avena sativa L.). Bulgarian Journal of Agricultural Science, 16 (4): 459-467

Nandi S., Das G., Sen-Mandi S. 1995. B-amylase activity as an index for germination potential in rice. Annals of Botany, 75: 463-467 http://dx.doi.org/10.1006/anbo.1995.1046
Navratil R. J., Burris J. S. 1980. Productive equations for maize inbred emergence. Crop Science, 20: 567-571 http://dx.doi. org/10.2135/cropsci1980.0011183X002000050004x

Nerson H. 2002. Relationship between plant density and fruit and seed production in muskmelon. Journal of the American Society for Horticulture Science, 127 (5): 855-859

Nik M. M., Babaeian M., Tavassoli A. 2011. Effect of seed size and genotype on germination characteristic and seed nutrient content of wheat. Scientific Research and Essays, 6 (9): 2019-2025

Panasiewicz K., Koziara W., Sulewska H. 2008. Parameters of vigor tests depending on seed size of some grain cereals. Fragmenta Agronomica, 1 (97): 297-306 (in Polish)

Ries S. K., Everson E. H. 1973. Protein content and seed size relationship with seedling vigour of winter wheat cultivars. Agronomy Journal. 65: 884-886 http://dx.doi.org/10.2134/ agronj1973.00021962006500060011x

Royo C., Ramdani A., Moragues M., Villegas D. 2006. Durum wheat under Mediterranean conditions as affected by seed size. Journal of Agronomy and Crop Science. 192 (4): 257$266 \mathrm{http} / / / \mathrm{dx}$. doi.org/10.1111/j.1439-037X.2006.00215.x

Rukavina H., Kolak I., Sarčević H., Satović Z. 2002. Seed size, yield and harvest characteristics of three Croatian spring malting barleys. Die Bodenkultur, 53 (1): 9-12 (in Serbian)

Seshu D. V., Krishnasamy V., Sidiqque S. B. 1987. Seed vigor in rice: proceedings of the international workshop on rice seed health. Manila, Philippines, p. 315-339

Singh N. D. 2003. Seed size and adventitious (nodal) roots as factors influencing the tolerance of wheat to waterlogging, Australian Journal of Agricultural Research, 54: 969-977 http://dx.doi.org/10.1071/AR02174

Sulewska H., Koziara W. 2006. Evaluation of sowing value and yielding potential of three fractions of maize seeds treated with Biochikol 020 PC. Journal of Research and Applications in Agricultural Engineering, 51 (2): 178-182

ISSN 1392-3196 / e-ISSN 2335-8947

Zemdirbyste-Agriculture, vol. 101, No. 1 (2014), p. 35-40

DOI $10.13080 / \mathrm{z}-\mathrm{a} .2014 .101 .005$

\title{
Paprastojo kukurūzo (Zea mays L.) derliaus kokybinių ir kiekybinių rodikliụ priklausomumas nuo sẻjai naudotų sẻklų dydžio Pietryčių Baltijos regione
}

\author{
H. Sulewska, K. Śmiatacz, G. Szymańska, K. Panasiewicz, H. Bandurska, R. Głowicka-Wołoszyn \\ Poznanės gyvybės mokslų universitetas, Lenkija
}

\section{Santrauka}

Selekcijos ir sėklininkystės ịmonės sėjai naudojamus ịvairių varpinių augalų grūdvaisius pagal dydị skirsto ị kelias grupes: mažus (1000 grūdų masès ribos $-\mathrm{x}-\mathrm{y})$, vidutinius $(\mathrm{y}-\mathrm{z})$ ir didelius $(\mathrm{z}-\mathrm{a})$. Tokie duomenys reikalingi veislès 'Boruta' paprastojo kukurūzo (Zea mays L.) augalus auginant Baltijos regione. 2005-2007 m. kukurūzus auginant lauko bandymuose siekta išsiaiškinti, ar sėjai naudoti didesnès masės grūdai sąlygoja didesnị ir kokybiškesnị būsimą derlių. Derliaus elementai buvo lyginami tarp kukurūzų, išaugintų iš trijų skirtingų dydžių grūdų.

Trejų metų lauko bandymų duomenys parodè, kad augalų derlius priklausè nuo sėklų dydžio frakcijos ir mažejo didèjant sèjamų kukurūzų sèklų dydžiui. Be to, tyrimų metu sẻklų daigumas nustatytas šaltuoju $\left(10^{\circ} \mathrm{C}\right)$ ir šiltuoju $\left(25^{\circ} \mathrm{C}\right)$ būdu. Didžiausias daigumas abiem būdais (atitinkamai 79,0 ir 74,0 \%) buvo nustatytas mažų sèklų frakcijoje. Nustatant šaltuoju būdu, didelių sẻklų daigumas buvo 6,71 \% mažesnis (skirtumas esminis) nei mažų sėklų. Visų trijų frakcijų amilolitinis aktyvumas nustatytas naudojant sausas ir mirkytas sėklas. Tyrimų rezultatai parodė amilazių didžiausią aktyvumą $\left(7,33 \mathrm{mg}\right.$ maltozès $\mathrm{g}$ sausosios medžiagos $\left.{ }^{-1} \mathrm{~min}^{-1}\right)$ mažose sèklose ir mažiausią aktyvumą $\left(4,12 \mathrm{mg}\right.$ maltozès g sausosios medžiagos $\left.{ }^{-1} \mathrm{~min}^{-1}\right)$ didelèse sèklose.

Reikšminiai žodžiai: amilazè, sėklų dydis, sėklų gyvybingumas, sėklų vertè. 